Poznań

\title{
European Groupings of Territorial Cooperation as an element invigorating integration processes at the local and regional levels in the European Union
}

\begin{abstract}
In the context of the mounting crisis of the European integration project, cross-border cooperation appears to be one of the dynamically developing exceptions. This in particular concerns the instrument of the European grouping of territorial cooperation (EGTC). Recent years have seen a considerable increase in the number of groupings established and initiatives aimed at establishing new ones. A more inquisitive approach to the development of EGTCs can produce different conclusions, however. On the one hand, EGTCs can exemplify the institutional pragmatism of local authorities, on the other - the implementation of EU member states' national policies. The purpose of this paper is to take a critical look at EGTCs as an element invigorating integration processes at the local and regional levels of the European Union. The author explores the different motivations and spatial differentiation of EGTCs that is emerging in the European Union. The premise of this paper is that in different parts of Europe, actors commit to establishing EGTCs for different reasons, which translates into the varying 'density' of EGTCs in specific EU macroregions. The analysis is conducted taking into account the main theories of integration in the field of European Union studies and the processes of international integration. The conclusion is that France and Hungary are the main European players with respect to EGTCs, although each state is stimulated by different factors.
\end{abstract}

Key words: EGTC, European Grouping of Territorial Collaboration, cross-border regions, Euroregions

\section{Introduction}

$\mathbf{T}$ he 2010s appear to be strongly marked by the regression of European integration processes as a consequence of a number of new challenges, such as economic turmoil in the aftermath of the financial crisis, an altered geopolitical situation accompanied by the neoimperial ambitions of the Russian Federation and the migration crisis. Yet another, and perhaps essential, factor is that the present formula of the unification of the continent based on overcoming Cold War divisions, the universal nature of the "European project" and the European Union's territorial expansion have become exhausted. The doubts both the political elite and societies of EU member states have are manifested in intensifying Euroskepticism, reluctance in admitting new EU members and the initiatives of specific states aimed at exiting the community.

This quite pessimistic picture of integration, however, displays a number of areas with high integration dynamics, including cross-border cooperation, and in particular the European Groupings of Territorial Cooperation (EGTCs). Recent years have witnessed a significant increase in the number of new groupings and initiatives to establish them. The analytical dimension of this trend is reflected in the rapidly expanding literature 
on this subject. The multitude of actors involved in these processes, ranging from state authorities to local communities, point to cross-border cooperation as an area that has escaped integration problems to some extent, where the orientation towards community is strong and the "European project" is efficiently implemented at the local level. A more inquisitive approach at the development of the EGTCs can produce different conclusions, however. On the one hand the EGTCs can exemplify the institutional pragmatism (Jańczak, 2011) of local authorities, on the other - the implementation of EU member states' national policies by means of this particular instrument.

The purpose of the analysis herein is to take a critical look at EGTCs as an element invigorating integration processes at the local and regional levels of the European Union. In an attempt to fill a research gap, it seems justified to inquire about different motivations and spatial differentiation of EGTCs that emerge in the European Union. The premise of this paper is that in different parts of Europe the actors commit to establishing EGTCs for different reasons, which translates into a varied 'density' of EGTCs in specific EU macroregions. The analysis will be conducted taking into account the main theories of integration in the field of European Union studies and the processes of international integration. Its methodology will be based on a statistical analysis carried out with reference to the EGTC register published on the EU Committee of the Regions' website and a comparative analysis conducted on the basis of extant academic studies, in particular case studies.

\section{Cross-border cooperation as interpreted by theories of integration}

In order to comprehend the dynamics of EGTC development, the reasons for specific actors to become involved in cross-border cooperation should be considered.

It can be assumed that a classical border and its fundamental role is a hindrance to development, among other things (owing to the border regime as well as legal, linguistic, administrative and other differences present on either side of it), and that cross-border cooperation is about transforming the border into a resource, opportunity and potential to develop (Järviö, 2011). The same applies to the identity and normative dimension where the traditional border separates social, cultural, legal and other systems, too. This is further reinforced by existing asymmetries (different pay levels, taxes, sanitary regimes and so on). Therefore, states are required to monitor their borders in order to maintain national, legal and organizational systems. This finds its political manifestation in the paradigm of a state's exclusive control over its territory and the postulate of "complete sovereignty" (Jańczak, 2013). The outcome is, however, that the potential of border territories cannot be utilized to the full, as this potential is typically produced by the differences between the territories on the two sides of the border and the possibility of taking advantage of these differences. EGTCs are therefore a new way of creating the bonds and mechanisms of improved cross-border governance, thereby stimulating development to an extent that is absent elsewhere. It may also pose a challenge to the traditional perception of territoriality and sovereignty.

Taking into account the above conditions, it should be noted that the main theories of European integration processes will provide different explanations of cross-border coop- 
eration as such, and of EGTCs. One additional reservation is required here, namely that both are perceived as endogenous components of integration processes. On the one hand, they are inspired and caused by the continent's integration (in terms of legal, financial and political instruments fostering integration) and on the other, they are the embodiment and manifestation of integration, both in its symbolic and practical dimensions.

Cross-border cooperation embedded in integration processes can be explained by means of a range of analytical instruments that are typical of European studies. Three main theoretical approaches are presented below: neofunctionalism, intergovernmentalism and constructivism.

Neofunctionalism consists in the neoliberal approach characteristic of the interwar and postwar period, and present first and foremost in US political thinking. Its core is the focus on functions and meeting needs. As a consequence, the liberalization of trade was perceived as the key instrument that inspired integration processes and facilitated their implementation (Haas 1964), where the elements related to economy served the purpose of attaining political stability and peace in international relations. This approach sees integration as fuelled by the logic of 'spill-over.' A successful integration initiative in a given thematic area inspires further ideas and integration spills over to new areas. "'Spill-over' refers to a situation in which a given action, related to a specific goal, creates a situation in which the original goal can be assured only by taking further action, which in turn create a further condition and a need for more action" (Lindberg, 1963, p. 123). Additionally, the ongoing erosion of nation-states is accompanied by transferring some powers that used to be traditionally reserved for a nation-state to a supranational level, thereby creating a level of strong supranational institutions.

If this explanation of integration is applied to the reality of cross-border cooperation and integration, the abandonment of border controls, customs duties and so on seems to be of key importance here. This process should invigorate economic development by means of goods and services exchange spilling over to new thematic areas. An EGTC is therefore a further, more advanced stage towards better fulfillment of local communities' needs. Initially, this can be achieved by exchange based on the difference of prices on both sides of the border. As the interaction spills over to other areas, such as environmental protection, culture, transportation, education, public services and so on, more advanced and improved management instruments are required.

Intergovernmentalism is rooted in the neo-realistic approach to international relations (Waltz, 1979). Integration is perceived primarily as a game played by sovereign states. On the basis of their national preferences and national interests, the representatives of these states negotiate a compromise in specific areas. The transfer of powers to a supranational level is not deemed desirable (Hoffmann, 1966) and it is sometimes instrumentalized (Moravcsik, 1993; Moravcsik, 1998).

The interpretation of cross-border cooperation is based on the state's national interest. In order to attain it, the actors from a non-central level are allowed to get involved in relations that go beyond the state borders. This policy, however, attempts to retain the highest possible level of control over cross-border processes. An EGTC is therefore a means to promote one's own national interest on a regional and local level, and a kind of organizational, cultural and economic expansion beyond the borders of one's state. 
Especially in the social dimension, constructivism is based on the premise of the social nature of integration which is founded on standards and values (Diez, Wiener, 2004). They emerge in the processes of mutual contacts and communication (Ruszkowski, 2007). Here, given the crisis of the main standards and values, individual actors propose new ones which spread in the process of socialization (Wilga, 2001, p. 48).

The interpretation of cross-border cooperation in this approach consists in the standardization and unification of normative and cultural systems occurring along the border, as well as in the potential to get to know and understand each other across this border. This type of integration is best manifested in cultural, educational and other projects. An EGTC is then an expression of shared culture, norms, languages and even ethnicities, allowing the relatively homogenous areas divided by the state border to reunify.

The above range of instruments provides an explanatory framework for the research questions posed in the introduction. Further analysis calls for the examination of the nature and development of the EGTC and its practical implementation in the European Union.

\section{EGTCs and their territorial distribution in the European Union}

Before EGTCs facilitated cross-border cooperation, this most often took the form of Euroregions (which remain to be the most popular and widespread). The nature of Euroegions consists in the voluntary cooperation of local government units (Scott, 2000 , p. 105) resulting in an association of partners located in the border regions of two or more states. Their primary goals typically include harmonious development in the area of culture, education, transportation, regional development, environmental protection, and so on (Mission). The history of Euroregions started after a successful Dutch-German project in 1958, whose idea was subsequently transferred to other Western European borders (Pasi, 2007, p. 74). After 1989, these models tested by European communities were imported by Central and Eastern European actors (Despiney, Zochowska, 2013, p. 80; Wassenberg, Reitel, 2015), who established a dense network of Euroegions in their territories and extended the integration project to their border areas before the states as such joined it (Scott 2000, p. 106). In this part of Europe in particular, cross-border cooperation based on Euroregional structures was ahead the process of unification with Western Europe, providing a certain laboratory of integration processes at a local level. Germany played a special role here, trying to overcome the difficult heritage of its territorial past (Grix, Knowles, 2002, p. 155). As a consequence, Euroregions have become a platform where interests of peripheries can be articulated, an instrument of the implementation of such interests (Scott, 2000, p. 104), an element of European Union structural policy, and the foundations of European cross-border governance (Jańczak, 2009).

Cross-border cooperation is determined by a twofold approach taken by EU member states. On account of political and economic benefits, such as gaining the image of a reliable and trustworthy party in integration processes, and intensified economic development of border areas, states promote the involvement of regional and local actors. On account of the dominant paradigm of sovereignty and territorial authority, 
they try to subject such cooperation to certain limitations and monitoring on the central level (Pete, 2014). The EGTCs are an excellent example here. Some member states extended the period of implementation of Community law, allowing them to establish EGTCs.

A European Grouping of Territorial Cooperation as an instrument to facilitate cross-border, supranational and supraregional cooperation in the European Union is defined by Regulation (EC) No. 1082/2006, article 175 of the Treaty on the Functioning of the European Union (TFUE) and Regulation (EU) No. 1302/2013 of the European Parliament and of the Council of December 17, 2013 amending the Regulation (EC) No. 1082/2006 on EGTC. Its fundamental goal is to design and implement joint projects of partners (such as EU member states, regional authorities, local authorities, public-law entities and the associations of entities from at least one of the above mentioned categories) with official seats in at least two EU member states. The key properties include legal personality, a unified budget and observing the law of the state where such an EGTC is registered. Given the extensive literature on the principles of EGTCs and the limitations of this text, a detailed presentation of their operating principles shall not be given herein.

A number of initiatives have emerged recently leading to the establishment of several dozen EGTCs. The first EGTC was established in 2008 on the French-Belgian border (Eurométropole Lille-Kortrijk-Tournai/Eurometropool Lille-Kortrijk-Tournai), followed by the EGTC on the Hungarian-Slovak border in the same year (Ister-Granum Korlátolt Felelősségű Európai Területi Együttműködési Csoportosulás/Európske zoskupenie územnej spolupráce s ručným obmedzením Ister-Granum) (Dumała, 2009, p. 65).

By virtue of Regulation (EC) No. 1082/2006 on a European grouping of territorial cooperation, the "members [of a new EGTC] shall inform the Member States concerned and the Committee of the Regions of the convention and the registration and/or publication of the statutes;" by virtue of art. 5.2 they are also obliged to send a request "to the Office for Official Publications of the European Communities for publication of a notice in the Official Journal of the European Union announcing the establishment of the EGTC" (Register, 2016); the Committee of the Regions carries the register of existing EGTCs and makes it available.

According to the data collected and presented in the Register of EGTCs (Register, 2016) there were 61 registered groupings as of March 16, 2016. The analysis of their territorial distribution shows that they differ in terms of popularity in different parts of the European Union (Table 1).

Table 1

European groupings of territorial cooperation

\begin{tabular}{|l|c|c|}
\hline & $\begin{array}{c}\text { No of EGTCs operating } \\
\text { in a given country }\end{array}$ & $\begin{array}{c}\text { No of EGTCs officially } \\
\text { seated in a given country }\end{array}$ \\
\hline 1 & 2 & 3 \\
\hline Hungary & 21 & 19 \\
\hline France & 19 & 11 \\
\hline Slovakia & 16 & 4 \\
\hline
\end{tabular}




\begin{tabular}{|l|c|c|}
\hline \multicolumn{1}{|c|}{1} & 2 & 3 \\
\hline Spain & 14 & 9 \\
\hline Italy & 9 & 5 \\
\hline Romania & 7 & - \\
\hline Germany & 6 & 1 \\
\hline Belgium & 6 & 1 \\
\hline Portugal & 5 & 3 \\
\hline Luxembourg & 5 & - \\
\hline Cyprus & 4 & - \\
\hline Slovenia & 3 & 4 \\
\hline Poland & 4 & 1 \\
\hline The Netherlands & 3 & 2 \\
\hline Greece & 3 & - \\
\hline The Czech Republic & 3 & - \\
\hline Austria & 2 & - \\
\hline Sweden & 1 & - \\
\hline Croatia & 1 & - \\
\hline Bulgaria & 1 & - \\
\hline Great Britain & - & - \\
\hline Malta & - & - \\
\hline Latvia & - & - \\
\hline Lithuania & - & - \\
\hline Ireland & - & - \\
\hline Finland & - & - \\
\hline Estonia & - & - \\
\hline Denmark & & - \\
\hline Total & 33 & - \\
\hline
\end{tabular}

Source: Own analysis based on the register of European groupings of territorial cooperation (Register, 2016) and the list of European groupings of territorial cooperation (List, 2016).

In national terms, Hungary (21), France (19), Slovakia (16) and Spain (14) host the biggest number of EGTCs. From the point of view of the official seat, which may be an indication of who is the leading agent in establishing and running the grouping, Hungary (19) and France (11) are the indisputable leaders in the area of cross-border cooperation based on EGTCs. These two states are surrounded by groupings on practically all their borders. They were also the initiators of EGTCs, establishing the first ones ever in 2008.

Another group is formed by states located in the neighborhood of the two above mentioned leaders or in Central Europe, with several EGTCs in each.

The last category comprises those states where EGTCs have not emerged, located primarily in the northern part of Europe (the Baltic states, part of Scandinavia and the British Isles)(Map 1).

These regularities present a diverse picture of regional and local cross-border cooperation based on EGTCs which clearly contradicts the crisis of the integration project. It also raises questions about the varying popularity of this form of relations. 


\section{Map 1. Distribution of EGTCs in the European Union}

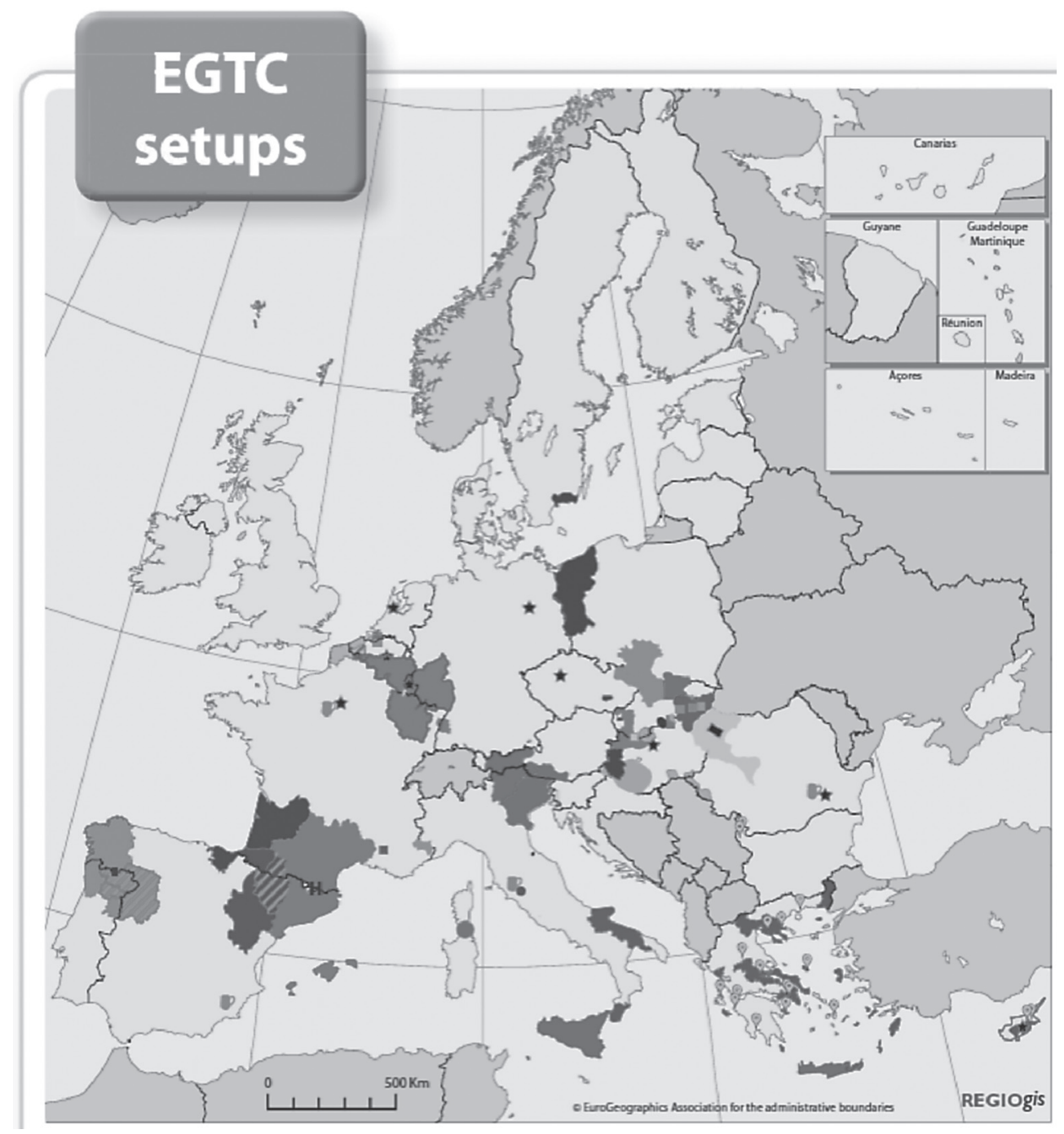

Source: Register, 2016

\section{Interpretation}

Seeking an explanation of the above mentioned irregularities in the territorial distribution of EGTCs and the leading role of France and Hungary in establishing them, theories of integration can be applied at the level of cross-border cooperation.

Northern Europe reveals a relatively high level of skepticism towards advanced integration processes. This attitude is primarily observed at the central level, providing a specific context for regional and local relations. A majority of the states in continental Europe have taken a pragmatic approach to the new instrument of EGTCs and have 
been testing it at the pace and in the forms that reflect the emerging possibilities, but apparently without enthusiasm, as was the case with Euroregions after 1989. France and Hungary are the leading states to have established EGTCs, a fact which demands further analysis.

The French case seems to be indicative of the neofunctionalist model. The degree to which French borders are open is high, and cross-border cooperation has been tested for a long time there. Additionally, over 500,000 French citizens have found employment in the border areas of neighboring countries, thereby providing an element of everyday economic cross-border movement. EGTCs therefore respond to the actual needs related to cross-border functioning. Cross-border integration, which follows the 'spill-over' logic, incorporating new territories, has demanded that new advanced structures to govern the cross-border reality be established in order to meet the existing needs better, and ensure more efficient cross-border governance.

The situation of Hungary is different, and issues of functioning are not essential. The constructivist and intergovernmental approaches appear to offer the best explanation for the Hungarian commitment to establishing EGTCs. The presence of million-strong Hungarian minorities right across the state's borders, and the resulting high level of cohesion in terms of ethnicity, culture and so on of the regions on both sides of the border (Nagy, 2014, pp. 95-96) suggests that this is the result of activities of Hungarian actors. This policy is strongly encouraged at the central level, which is explained in terms of intergovernmental logic as a manifestation of the national interest oriented towards the reconstruction of ties between Hungarian minorities abroad and the nation proper. The concept of national policy, which prevails in domestic and external relations, is founded on Hungarianness, understood as the conjunction of Hungarians in Hungary, with Hungarians in neighboring states and other countries. Cross-border policy, in turn, can be defined as the debordering of the state (manifested as a liberalized state border regime and intensified cross-border cooperation) accompanied by the simultaneous rebordering of the nation ${ }^{1}$ (which means influencing the Hungarian minorities in the neighboring countries and, by doing so, separating them from the mainstream of how their states of residence function) (Nyyssönen, 2011, p. 60). The Hungarian government offers considerable aid to studies into cross-border cooperation with its Hungarian neighbors, which can be exemplified by the organizational and financial support of the European Institute of Cross-border Studies (European, 2016),

\section{Conclusions}

The attempt this paper makes to take a critical look at the instrument of EGTCs as an element invigorating integration processes at the local and regional levels of the European Union has demonstrated two dimensions of this phenomenon. On the one hand, it shows that despite the continental crisis of integration, EGTCs, which exemplify crossborder cooperation and integration, are emerging dynamically in different parts of the European Union. On the other hand, however, their considerable spatial diversification

${ }^{1}$ As expressed by Heino Nyyssönen: "De-Bordering the State - Re-Bordering the Nation" (Nyyssönen, 2011). 
has been demonstrated. Their absence in Northern Europe is in stark contrast to France and Hungary, which host nearly half of all groupings. In order to explain this asymmetry, the classical theories of European integration studies have been employed. The northern part of Europe seems to be dominated by an intergovernmental vision of integration and a reluctance to get involved in new cross-border solutions threatening that further elements of sovereignty will be transferred beyond the nation-state. The French example provides an illustration of a neofunctionalist approach, where the establishment of EGTCs is motivated first and foremost by the desire to meet the needs related to the everyday cross-border activities of French citizens. In the case of Hungary, it is an element of state policy, related to the reconstruction of ties with the regions inhabited by Hungarian minorities abroad. The theories of intergovernmentalism and constructivism convincingly explain the mechanisms of the respective state's involvement in this form of cooperation.

\section{Bibliography}

Despiney Zochowska B. (2013), Euroregions, Emerging new forms of Cross-border cooperation, in: Borders and Border Regions in Europe. Changes. Challenges and Chances, eds. A. Lechevalier, J. Wielgohs, Transcript, Bielefeld.

Diez T., Wiener A. (2004), European integration Theory, Oxford University Press, Oxford.

European Grouping of Territorial Cooperation (2015), www.protal.cor.euriopa.eu, 14.12.2015.

European Institute of Cross-border Studies, www.institute.cesci-net.eu, 05.05.2016.

Dumała H. (2009), Europejskie Ugrupowania Wspótpracy Terytorialnej - nowe możliwości dla polsko-niemieckich euroregionów, in: Pogranicze polsko-niemieckie na tle granic i pograniczy europejskich, eds. J. Jańczak, M. Musiał-Karg, L. Wojnicz, Wydawnictwo Naukowe WNPiD UAM, Poznań.

Grix J., Knowles W. (2002), The Euroregion and the Maximization of Social Capital: Pro Europa Viadrina, "Regional and Federal Studies", no. 12, vol. 4.

Haas E. (1964), Beyond the Nation State. Functionalism and International Organisation, Stanford University Press, Stanford.

Hoffmann S. (1966), Obstinate or obsolete. The fate of the nation-state and the case of Western Europe, "Daedalus", vol. 95, no. 3.

Jańczak J. (2011), Cross-border Governance in Central European Border Twin Towns. Between Debordering and Re-bordering, in: De-bordering, Re-bordering and Symbols on the European Boundaries, ed. J. Jańczak, Logos Verlag, Berlin, pp. 37-52.

Jańczak J. (2013), Border Twin Towns in Europe. Cross-border Cooperation at a Local Level, Logos Verlag, Berlin, p. 135.

Jańczak J. (2009), Cross-border governance jako koncepcja wspólnego zarzqdzania miastem podzielonym. Efektywność w warunkach członkostwa w UE, in: Pogranicze polsko-niemieckie po 2004 roku. Nowa jakość sqsiedztwa?, eds. J. Jańczak, M. Musiał-Karg, Wydawnictwo Adam Marszałek, Toruń, pp. 214-237.

Järviö P. (2011), Cross-border cooperation - benefiting from borders, Jarvio Associates, Ministry of Foreign Affairs of Finland, Helsinki.

Lindberg L. N. (1963), The Political Dynamics of European Economic Integration, Stanford University Press, Stanford, CA.

Mission Opérationnelle Transfrontalière (MOT), http://www.espaces-transfrontaliers.org/en/resources/ territories/euroregions/, 15.11.2015. 
Moravcsik A. (1993), Preferences and power in the European Community: A liberal intergovernmentalist approach, "Journal of Common Market Studies", vol. 31, Issue 4.

Moravcsik A. (1998), The Choice for Europe: Social Purpose and State Power from Messina to Maastricht, Cornell University Press, Ithaca.

Nagy Á. (2014), Some Characteristics of European Groupings of Territorial, Cooperation in BorsodAbaúj-Zemplén County, "Cross-Border Review".

Nyyssönen H. (2011), De-Bordering the State - Re-Bordering the Nation: "Nation Policy” in Hungary, in: De-bordering, Re-bordering and Symbols on the European Boundaries, ed. J. Jańczak, Logos Verlag, Berlin.

Pasi P. (2007), Euroregions as Micro-Models for European integration, in: Euroregions in Alp-Adriatic Context, ed. J. Langer, Peter Lang, Frankfurt am Main.

Pete M. (2014), Investigating the Role of Borders in the Transformation of Space in the Light of the European Union's Regional Policy, "Cross-Border Review".

Register of European grouings of territorial cooperation, https://portal.cor.europa.eu/, May 6, 2016.

Regulation (EC) No. 1082/2006, on the basis of article 175 of the Treaty on the Functioning of the European Union (TFUE).

Regulation (EU) No. 1302/2013 of the European Parliament and of the Council of December 17, 2013 amending the Regulation (EC) No. 1082/2006 on EGTC.

Ruszkowski J. (2007), Wstęp do studiów europejskich. Zagadnienia teoretyczne i metodologiczne, PWN, Warszawa.

Scott J. W. (2000), Euroregions, Governance and Transborder Cooperation within the EU, "European Research in Regional Science", vol. 10 (Border, Regions and People).

Waltz K. (1979), Theory of International Politics, Addison-Wesley, Reading MA.

Wassenberg B., Reitel B. (2015), Territorial Cooperation. A Historical Perspective, Publications Office of the European Union, Luxembourg.

Wilga M. (2001), Integracja europejska w konstruktywizmie, "Przegląd Politologiczny", no. 1-2.

List of European groupings of territorial cooperation (EGTC) (2016) established and submitted to the European Committee of the Regions in compliance with art. 5 of the Regulation (EC) No. 1082/2006of the European Parliament and of the Council, Brussels, March 16, 2016.

\section{Europejskie Ugrupowania Współpracy Terytorialnej jako element dynamizacji procesów integracyjnych na poziomie lokalnym i regionalnym w Unii Europejskiej}

\section{Streszczenie}

W kontekście narastającego kryzysu projektu integracyjnego w Europie to współpraca transgraniczna wydaje się być jednym z dynamicznie rozwijających się wyjątków. Dotyczy to w szczególności instytucji Europejskiego Ugrupowania Współpracy Terytorialnej (EUWT). Ostatnie lata to znaczący przyrost ilości utworzonych ugrupowań oraz inicjatyw zmierzających do ich powołania. Jednakże bliższe spojrzenie na rozwój EUWT może sugerować bardziej złożony obraz sytuacji. Z jednej strony, bowiem stanowić mogą one przejaw pragmatyzmu instytucjonalnego jednostek samorządu terytorialnego, z drugiej, realizacji polityk narodowych państw członkowskich.

Celem prezentowanego tekstu jest krytyczne spojrzenie na instytucję EUWT jako elementu dynamizacji procesów integracyjnych na poziomie lokalnym i regionalnym w Unii Europejskiej. Autor stawia pytanie o zróżnicowanie motywacyjne i przestrzenne tworzonych EUWT w Unii Europejskiej. Zakłada on, iż aktorzy w różnych częściach Unii Europejskiej angażują się w tworzenie ugrupowań z uwagi na odmienne czynniki, co przekłada się na zróżnicowaną „gęstość” ich występowania w poszczególnych makroregionach wspólnoty. Analiza przeprowadzona została przez pryzmat głównych 
teoretycznych szkół integracyjnych w obszarze studiów nad Unią Europejską i procesami integracji międzynarodowej. Wnioski pokazują Francję i Węgry jako głównych graczy w Europie w zakresie EUWT, każde z tych państw motywowane jest jednak przez odmienne czynniki.

Słowa kluczowe: EUWT, Europejskie Ugrupowanie Współpracy Terytorialnej, regiony transgraniczne, euroregiony 
